\title{
Integration of Local Wisdom with Environmental Law
}

\author{
Matnuril $^{1}$, Murthir Jeddawi ${ }^{2}$, Kusworo $^{3}$, Bambang Supriyadi ${ }^{4}$ \\ Program Doktoral Pascasarjana Institut Pemerintahan Dalam Negeri, Indonesia \\ Email: nuril.tapem@gmail.com
}

\begin{abstract}
This study aims to identify the values of local wisdom with an insight into environmental law owned by the people of Nagari Pariangan. This research uses a qualitative approach with descriptive methods. Research data collection using observational methods, focus group discussions, interviews, and documentation. The results showed that the values of local wisdom of Nagari Pariangan as a guide to people's lives in protecting their environment are manifested in customary norms that natural resources in the form of land/fields/ rice fields, forests and rivers cannot belong to individuals but belong to indigenous people/tribes and in its management must obtain approval from Ninik Mamak. The Tigo Tungku Sajarangan government integrates the customary norms of Nagari Pariangan with environmental laws that are realized in consensus agreement between Ninik Mamak in every development plan that is proclaimed by the Nagari Government, Regency, Provincial and Central Governments. If the results of the consensus were unanimous then that would be the final decision carried out by each of the nephews/ community's children.
\end{abstract}

Keywords: Integration, Local Wisdom, Environmental Law.

\section{A. INTRODUCTION}

As a country that was awarded the islands both large and small, Indonesia has the opportunity for the development of a bright future for tourism. This is not only due to the opening of opportunities to reach the increasing number of world tourists but also due to the potential wealth of available resources, especially natural and cultural resources that are in demand for the world-minded world tourism market. Because of its rich natural and cultural resources, rural areas have strong potential to meet the demands of the tourist market. The tourism sector is one sector that can be relied on to encourage tourism growth in the village will not only be able to improve the local economy, but also increase socio-cultural values and environmental preservation. One type of tourism that is very suitable for rural conditions is the Tourism Village Concept.

Nagari Tuo Pariangan is one of the Nagari / Villages that has successfully implemented the Tourism Village Concept. Nagari Pariangan which is located on the slope of Mount Merapi is located in the Tanah Datar District of West Sumatra Province. Since the release of the American Travel Budget tourism magazine as one of the most beautiful villages in the world (World Number 5), Nagari Pariangan has not only suddenly become famous but is slowly also beginning to feel the economic impact of the tourism sector with special interest criteria. 
Nagari Tuo Pariangan is a Nagari that has its own privileges for the Minangkabau people. The historical record recorded in Tambo Minangkabau shows that Nagari Pariangan is a Nagari from the Minangkabau tribe, which is referred to by the local community as the Minangkabau Natural Stove. That is, Nagari is believed to be the first place for the emergence of life in the Minangkabau world hundreds of years ago. In Nagari Tuo Pariangan there are many historical relics from the past which is evidence of the origin of the Minangkabau tribe.

Special interest tourism is developed in an effort to optimize resources to advance the tourism sector. This is in accordance with what is stated in Article 20 of Law Number 9 of 1990 concerning tourism which says that; the management of objects and attractions of special interest is an effort to utilize natural resources and the potential of the nation's art and culture to generate special interest as a tourist destination. The conception of sustainable development in the tourism sector emphasizes the importance of integration between tourism development ideas and environmental management. The general objective of environmental management is the realization of sustainable development, meeting the interests of present and future generations.

By looking at this phenomenon, the purpose of this study is to analyze and illustrate the integration of local wisdom with the principles of environmental law in Nagari Pariangan, Tanah Datar District, West Sumatra, West Sumatra Province.

\section{B. LITERATURE REVIEW \\ 1. Conception of Integration}

Social integration will be formed in the community if most members of the community have an agreement on the territorial boundaries of a region or country where they live. In addition, the majority of these communities agree on social structures that are built and implemented, including values, norms, and even higher are social institutions that apply in their communities, in order to maintain the existence of these communities. Social norms and values that apply for a long time and run consistently and do not change so that it can be a standard rule in carrying out the process of social interaction. In addition, the characteristics that are formed as well as mark the boundaries and patterns of society.

William F. Ogburn and Nimkoff (1964), said the conditions for successful social integration are:

a. Community members feel that they have successfully filled one another's needs with one another. This means that the physical needs of clothing and food and their social needs can be fulfilled by their culture. The fulfillment of these needs causes the community to maintain mutual engagement with one another.

b. The community has succeeded in creating consensus about social norms and values that are preserved and used as guidelines in interacting with one another, including agreeing on things that are prohibited according to their culture. 
J. P. Gillin and J. L. Gillin (1954), defines society as "the largest grouping in common customs, traditions, attitudes, and felling of unity are operative". Departing from this definition, it can be understood that a society is: (1) a group of people who occupy a certain area, (2) they live for a relatively long time, (3) there are rules of life such as customs, habits, attitudes, and feelings of unity, (4) a sense of identity among its citizens. community integration will be achieved if all the elements of community life have been fulfilled and vice versa if one of the elements is not fulfilled then the condition of the community is no longer integrated.

\section{Legal Conception}

Law as a global phenomenon has similarities throughout the world, in the sense that everywhere law consists on the basis of ethical values, social norms, and rules made by the state, although of course, in reality, there are many cultural variations. more specific. By using the three main types of legal approach, namely the law created by society, the law created by the state and the law that arises through values and ethics. That the three elements are plural.

According to Menski (2006), to introduce a graphical representation of the level of intrinsic the second legal pluralism, starting with the law found in social life, because in social life that is the place where the law is always located. That there is no society without law, at the central axis in the triangle of society, social norms, and processes that produce some validity and authority from the ethical environment and values. Overall, the intrinsic image of legal pluralism is found in the triangle of society. It proves that this is also a life of truth, but a culture which is perhaps also intrinsically plural and extends into the life of the state and to the realm of values. Thus, it means that cultural analysis will also benefit from the application of plurality-conscious analytical methods.

\section{The conception of Indonesian Environmental Law}

The necessity to uphold environmental law is inseparable from the context or chronology of international environmental law that began in the United Nations Conference on Human Environment (Stockholm, United Nations Conference on Human Environment) in Stockholm 5-6 June 1972, Sweden, where Indonesia is one of the participants. The conference was known as the Stockholm Declaration which succeeded in pushing other international conventions such as the Paris Convention (1974), the London Convention (1976), and The Hague Convention. Although it is only a soft law and a codification of the principle or adenium of international customary law as stated in principle 21, it must be obeyed by the international community in forming their respective national laws. For example, principle 22 requires international countries to develop international environmental law, especially those relating to liability and compensation. As cited below: "States shall cooperate to develop further the international law regarding liability and compensation or victims of population and other environmental dam- 
age caused by activities within the jurisdiction or control of such states to areas beyond their jurisdiction".

The Stockholm Declaration asks participating countries to try to find a solution to the dichotomy between development interests and environmental interests as successfully formulated in principle 1 which reads: "Man has the fundamental right to freedom, equality and adequate conditions of life, in an environment of a quality that permits a life of dignity and well-being, and it bears a responsibility to protect and improve the environment for present and future generation.

Based on principle 1 above, humans are considered to have a solemn responsibility to protect and improve the quality of the environment for present and future generations. However, because it was ineffective, the Stockholm Declaration encouraged the UN meeting on the environment in Nairobi (1982) by giving birth to the Nairobi Declaration, until the formation of the UN body namely the World Commission on Environment and Development (WCED) to study in-depth about the implementation of the Stockholm Declaration which resulted in principles Sustainable Development, until the Rio de Janeiro Conference, Brazil in 1992 on the Environment and Development (the United Nations Conference on the Environment and Development), which was followed by 178 countries and came to be known as the 1992 Rio Declaration (the Earth Summit). Basically besides accepting the principle of Sustainable Development (Rahmadi, Sustainable Development in the Era of Decentralization, 2001).

The 1992 Rio Declaration produced 27 principles of environmental law. Of the 27 principles, there are ten principles that are important elements of "Sustainable Development" as well as being the basic principles of the new environmental law adopted in the Statutory Regulations of countries in the world including Indonesia, as follows:

a. State sovereignty and responsibility (sovereignty/responsibility of the State);

b. Intergenerational equity responsibility (the responsibility of the generation of acuity);

c. Intragenerational equity responsibility;

d. Integral development process;

e. Common but differentiated responsibilities;

f. Preventive action;

g. Good neighborliness;

h. Precautionary;

i. Cost internalization;

j. Democracy and public participation (Husin, 2004).

Although from the Stockholm Declaration to the Rio Declaration it took 20 years, for Indonesia, it has ratified it into national environmental law ten years after the Stockholm Declaration. As in accordance with the affirmation of the conclusion of the International Environment Conference in The Hague that Rio's principles must be absorbed into national and international law and given a high status at the national, provincial 
and district/city level in order to become guidelines for policymakers/decisions, administrators, judges, community and citizens, namely through the modification or formulation into various national laws and regulations.

Based on this consideration, the government has issued various laws and regulations relating to the environment and has included the principle of sustainable development as a development paradigm as outlined in TAP RI MPR Number II of 1993 concerning the State Policy Outline (GBHN) which then spelled out in various laws and regulations. Specifically for sustainable development at the regional level, the Ministry of Home Affairs of the Republic of Indonesia has compiled "Agenda 21 as a General Guideline Blueprint for Preparation of Sustainable Development Planning in the Regions".

To anticipate environmental destruction as a negative impact from the rapid development, the government has issued Law Number 32 of 2009 in lieu of Law Number 23 of 1997 concerning Environmental Management. Basically the law contains three environmental law enforcement namely; (1) Administrative law enforcement; (2) Civil law enforcement; and (3) Criminal law enforcement. Law enforcement is not only important but it is imperative that physical development in various regions does not cause the effects of environmental pollution above the tolerance threshold.

\section{METHOD}

This research was conducted in Nagari Tuo Pariangan, Pariangan Subdistrict, Tanah Datar, West Sumatra Province, using qualitative descriptive methods (Kusmayadi and Sugiarto, 2000). Informants in this research include 2 types, namely key informants and key informants (Suyanto, 2005). Key informants are 1 traditional leader, 1 Wali Nagari. Whereas the main informant consisted of 4 heads of Jorong Nagari Tuo Pariangan. Data collection in this research uses observation techniques, interviews, and documentation studies. In accordance with the research method, the data analysis technique used by the author in this study is a qualitative data analysis technique. Technical analysis of data in this research refers to the concept of Miles \& Huberman (1992), an interactive model that classifies analysis in three steps, namely data reduction, data presentation, and drawing conclusions.

\section{Result AND Discussion}

Nagari Pariangan, West Sumatra Regency, West Sumatra regency administration system consists of:

\section{Custom Salingka Diri}

This traditional teaching is about how to place a person as something that is not private property that can act as they wish, always live and grow in the community in Nagari Pariangan. The way of life of the Nagari Pariangan community is regulated in the tradition that the self is a kamanakan mamak, as the teachings say: "...Kamanakan 
mamak, anak dari mandeh juo ayah, cucu dari atuak, dan adolah juo mamak urang. Ado bisan, dan bako. Kamakanakan barajo kemamak, mamak barojo kapanghulu, panghulu barajo ka nan bana, nan bana badiri sandirinyo". (Nephew Mamak, child of mother and father, grandchildren of grandfather, and there are also other Mamak. There are father-in-law and Bako / sister from father. Nephew learns to Mamak, Mamak learns to the headman, the headman learns to the right, the right standing alone Him (what is meant by itself is religion, that is Allah SWT).

The headman as a leader in the people. All of these have customary rules for behaving and acting. The headman is a leader in his people, one who is appointed and raised by his people to guide and lead his people. The leadership of a leader is highly recognized and respected as "gantiang putih"; who decides all the problems in his people. He is respected and respected because he was given the title Pengulu who was given the title Datuak as the title "sako" for generations. "...Pai tampek batanyo pulang tampek babarito, dahannyo gadang, daunnyo rimbun, ureknyo tunggang". (Going to were to ask home were to preach, the branches are large, the leaves are thick, the roots are riding).

\section{Custom Badunsanak.}

This customary teaching is about how to act and behave must weigh other people: "...Adiak kadunsanak, adiak ka adiak, adiak kamamak", and etc. This customary teaching shows that each person is an inseparable part of everyone else: "...Tagak dunsanak badunsanak, tagak kampuang bakampuang, tagak nagari banagari". This means that the people of Nagari Pariangan uphold customary family and community togetherness. "...Sadanciang bak basi, saciok bak ayam". If there are problems and disputes do not have to be brought directly to the Nagari level or the police, but there is a tiered step up and down, so it must be deliberated or resolved first among the people. These values of togetherness must be and continue to be used by the people of Nagari Pariangan, and if anyone does not use them they will be displaced by themselves and usually left to live alone (ostracized).

\section{Custom in Family.}

This traditional teaching is about how to act and behave in the family. The family in the Nagari Pariangan traditional teachings is the smallest group responsible for the people to implement the same custom in the village. Embarrassment for families is a shame for their people. Thus, this traditional teaching is very much guarded by the application of courtesy values: "...raso jo pareso, mangarati jo nan ampek dan menjauhi sumbang jo cemo". (Sense is examined, understood with the four and away from wrong and blasphemy. The four meanings are; Imam, Khattib, Bilal and Khadi). Because, if families and people have been insulted / despicable in Nagari it is difficult to restore its image in the midst of society. In a long time will continue to feel condemned by itself / shame. Customary law is rarely written but the consequences are highly psychologically influential in the Nagari Pariangan community). 


\section{Urang 4 Jinih.}

Urang 4 jinih traditional institutions in the Nagari Pariangan traditional teachings are; Penghulu, Malin, Manti, Dubalang. The headman is the leader of his people. Malin is derived from the word mua'allim, which is a body that takes care of and serves religious affairs. If a problem occurs in Nagari it will be he who will try and punish. Likewise in marriage, divorce, qadi, birth, death, and others related to religious matters. Manti is the accomplice of the headman who manages and serves as the intermediary/liaison of the head of all matters, especially if the headman is unable. Dubalang Kato Mandareh, as the custom is called. Serves in the main business which is related to security and oversees all actions of children who deviate from traditional teachings and religion. "...Adat basandi sarak, sarak basandi kitabullah". (Customs are based on sarak, sarak is based on the Book of Allah / the Qur'an).

\section{Jinih Nan Ampek.}

Rang jinih nan ampek traditional institutions are the main implementers in the religious field, he collaborates with Penghulu Nagari as the leading executor in religious matters. The urang Jinih Nan Ampek is; Imam, Khattib, Bilal and Kadhi. An Imam is a person who is upright at the door of the makrifat, meaning a person who will become a religious instructor in the people and village, as a role model, becoming a prayer leader in Surau and the Mosque. Khattib, is a Friday congregation preacher. Or it means that he is a people. "...Kato katik kato dimuaro tagak dipintu tarikat". (The word khattib is a word in the estuary upright at the door of the Tariqa). Bilal, is the muezzin who is in charge of the call to prayer at the time of entry and Friday prayers at the mosque. "...Kato bila kato maimbau". (Bilal words appeal). Khadi, his job is to try and resolve cases involving religion, marriage, divorce, reconciliation and marriage counselors. 


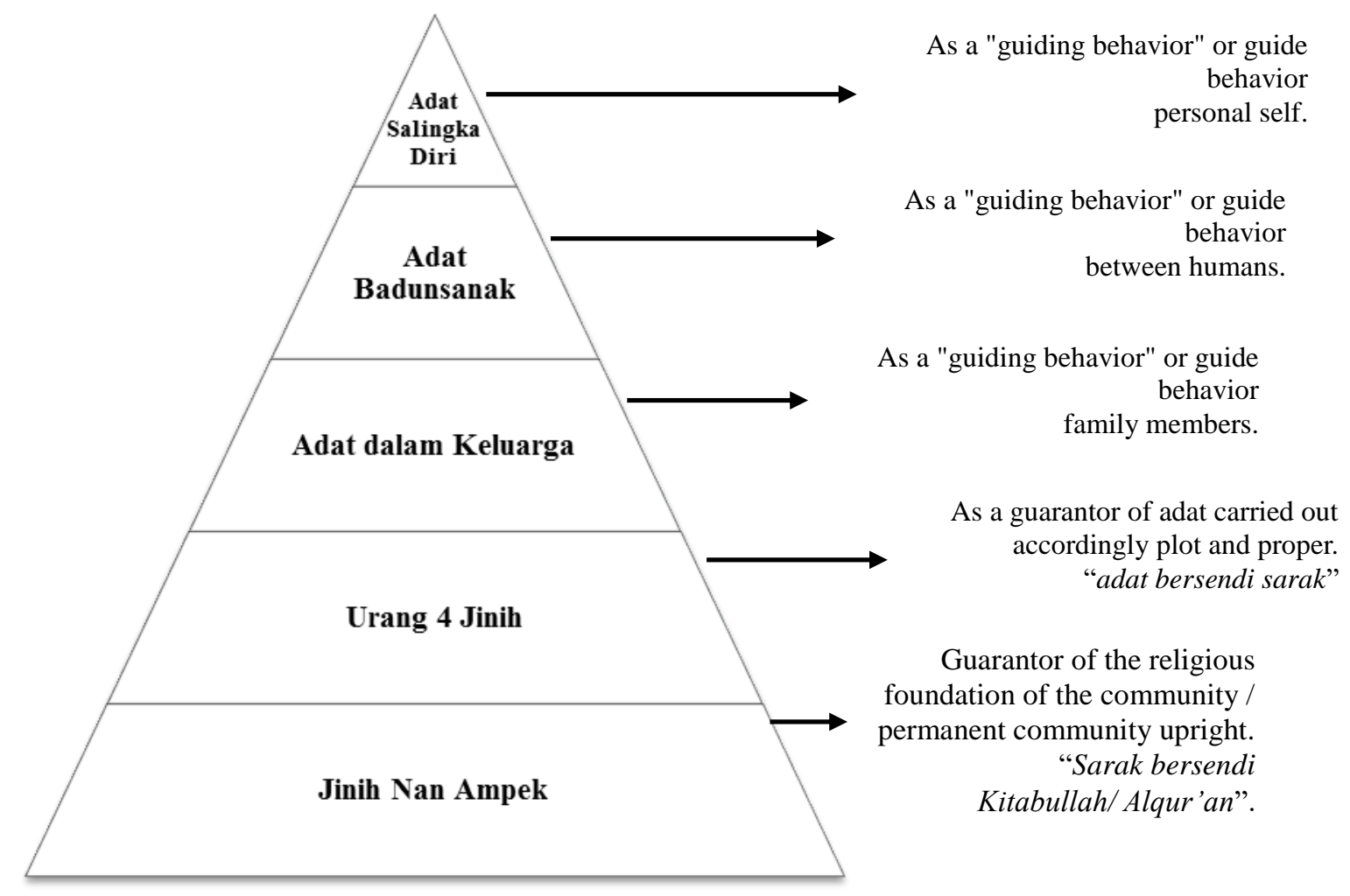

\section{Figure 1 Customary Institution in Nagari Pariangan}

From the customary pyramid in Nagari Pariangan, it can be understood that the types of laws that apply in the community are directly sourced from the products of customary norms, and the customary norms actually originate from religious norms. It is relatively small and even invisible, but still binding and obeyed as formal legislation in its environment. However, whatever form it takes and whatever shape it, the institution reflects the fact that it is a type of law. The achievement of the law lies in the wisdom of the people of Nagari Pariangan who have succeeded in creating consensus (consensus) regarding social norms and values that are preserved and used as guidelines in interacting with one another, including agreeing on things that are prohibited according to its culture.

In customary settings, the Nagari Pariangan community at the highest level teaches moral and ethical philosophy. "Custom of mutual self" is a moral and ethical philosophy that guides the self-behavior of the people. This philosophy in the theory of tri-angular legal concepts of legal pluralism is called legal behavior. Environmental law based on rights theory is also influenced by moral philosophy or ethics (Takdir Rahmadi, 2012: 35). The philosophy of this view is that actions that cause pollution and environmental destruction are evil actions (evils) so that the community or the state is obliged to provide punishment. The phenomenon of environmental law based on the theory of paternalism is also an integration of the values of local wisdom. The philoso- 
phy of paternalism means that the state is responsible and plays a role as a parent in guiding the behavior of its people (Rahmadi, 2012).

The customary norms of "self-respect" that apply and are held in high regard by the people of Nagari Pariangan, if observed, are actually set forth in the concept of Indonesian environmental law. The concept of placing oneself as something that is not personal property that can act at will / arbitrarily has a philosophical meaning will be important. What we do actually have the potential to impact on other people and even future generations. As stipulated in Article 87 paragraph (1) of Law Number 32 the Year 2009 concerning Environmental Protection and Management, reads:

"Every person in charge of a business and/or activity that commits a violation of the law in the form of pollution and/or damage to the environment which inflicts losses on others or the environment must pay compensation and/or take certain actions".

Thus, Indonesia's positive legal norms, especially those relating to the understanding of environmental management that are in harmony with customary norms " salingka diri, adat badunsanak, adat dalam keluarga" reflect the integration of human attitudes and behavior from two different legal phenomena. Article 87 paragraph 1 is directed to prevent acts that not only harm oneself, but also other people as a whole, and to direct the citizens' preferences for the good in a sustainable manner. It's just that, in positive law material sanctions are often put forward. In the view of the people of Nagari Pariangan, for the good of the environment, all contents of Nagari must use the customs and laws that have been taught as follows:

"Kata raja kata melimpahkan. Kata penghulu kata menyelesaikan menurut alur dan patut, menurut baris dengan belebas. Kata alim ulama kata hakekat. Kata pegawai kata penghubung. Kata orang muda kata merdesa. Kata orang banyak kata bergalau. Kata perempuan kata merendah mengambil hati suaminya, menurut kata Ninik Mamak dan orang tuanya". (Diradjo, 2009).

The meaning of the word alur is a word that means straight and true. If the people in Nagari did not use the aforementioned law, it could be said that Nagari was not possessed, so Nagari would not have survived. In another section, Diradjo in his book Tambo Alam Minangkabau explains that there are 6 cases that are owed by every elderly and clever man in Nagari:

First, it is obligatory for them to remind their experts and those who believe in them about their mannerisms slipping from good behavior and order, or from customs called courtesy (adat salingka diri). Second, let them give instructions to all their relatives and to all who believe in him the good way and how orderly and mannerisms that should be used by them. By denying all mannerisms of those who are in conflict with proper customs, they are then given good teaching, so that these people discard their bad conduct. 
Third, let the old and clever old people say that with perfect knowledge and knowledge guide their relatives and those who believe in him with a pure and sincere heart. Fourthly, when you say those old and clever people in their all-round knowledge, you cannot help but soften the hard heart of a person by his deception, and loosen up the tense because of his clever words to do good advice to those who hear and receive that advice.

Fifth, it is obligatory for clever and smart parents to tell their relatives and those who believe in them about good stories and bad stories, things that have happened that they have seen and heard, stating their bad and good marks in order to become teaching and a warning to his people and to those who believe in him. Sixth, let the smart and clever old men declare themselves, that is, declare their close relations with all these people, so that they will increase their affection for them. If this is the case, it will make it easier to give good advice to advance difficult work in Nagari.

In addition, in the Nagari Pariangan traditional law enforcement aspects place non-material sanctions as the highest sanctions, in addition to the existence of material sanctions. The highest form of non-material sanctions is not included "se ilir dan se mudik dalam Nagari". This means that no dizziness is taken, left alone or ostracized, and this is the heaviest form of punishment in Nagari Pariangan traditional institutions. If this punishment has been imposed on a person or a group, usually that person or group tends to leave Nagari because they feel ashamed and there is no place for him anymore. Thus it can be understood that the philosophy of togetherness underlies law enforcement in customary institutions in Nagari Pariangan. "Kamanakan barajo kamamak, mamak barajo kapanghulu, panghulu barajo ka nan bana".

The customary goals of Minangkabau, especially Nagari Pariangan, actually lead to the ideals of realizing a just and prosperous society. In the view of indigenous peoples, these ideals will not be achieved if there are no customary norms that govern them. The Minangkabau predecessors namely Datuk Ketu-Manggunangan and Datuk Parpatih Nan Sabatang have drafted customary laws that are used as guidelines and experiences to realize just and prosperous ideals.

The drafted law plays an important role in strengthening the customary institutions of the Minangkabau people. Perhaps this is why the Minangkabau people are still thick with their customs because the inheritance it receives is based on customary laws and regulations that are still written and must be guided, lived and practiced by the people. The law drawn up by the Minangkabau predecessors is categorized in 4 parts or in the Minangkabau custom called " Undang-undang nan ampek " namely; (1) Undangundang luhak dan rantau; (2) Undang-undang Nagari; (3) Undang-undang dalam Nagari; dan (4) Undang-undang nan Duopuluah.

The Luhak and Overseas Laws regulate luhak and overseas areas such as the duties of the headman and king in the overseas area. The Nagari Law regulates everything about Nagari as a unified customary community. The law in Nagari regulates the rela- 
tionship between Nagari and its contents, between someone and someone and between someone and the community and so on, and regulates and outlines the rights and obligations as members of indigenous peoples. Whereas Undang-Undang nan Duopuluh regulates criminal law issues, which are divided into two parts namely; (a) Undang-Undang Nan Dekapan; (b) Undang-Undang Nan Duobaleh.

In this law, there is no threat of punishment. Because the threat of punishment for people who violate the law is not in accordance with the communal system based on collectivity. Because everyone is a member of the commune, in this case, called clan or tribe. From that, the people or tribes have a responsibility for the behavior of their members. If someone commits a crime that deserves to be punished, then the one who will carry the punishment is the people or tribe of the perpetrators of the crime. As for the perpetrators themselves, the people or their tribes will sentence them. In a collective communal society such as Pariangan in particular, and the Minangkabau generally view that every human being is his people, each group is a citizen who must be respected and glorified with the same principle. Their life principle is patterned on togetherness and equality. The threat of punishment for convicted of crimes is based on the principle of the family "awak samo awak".

Nagari Paraiangan's governance is led by Nagari Mayor and his apparatus is appointed through the Nagari Guardian Election, or called Pilwana. Nagari Pariangan consists of 4 Jorong (Jorong Guguak, Jorong Sikaladi, Jorong Pariangan, and Jorong Padang Panjang), each of which is led by an individual Chief Jorong. Traditionally, Nagari Pariangan also has a Nagari Customary Office (KAN) which has an office in the Wali Nagari Office with a structure of Chairperson, Secretary, Treasurer, and Members. Concerning adat issues will be fully regulated by the Adat Chief of Nagari in collaboration with Wali Nagari and Bundo Kanduang. Here it can be understood that the highest power in decision making towards Nagari Pariangan rests with the Chief of the Indigenous Nagari because it is a compilation of all Ninik Mamak Nan Gadang Basa Batuah. "Pai tampek batanyo, pulang tampek babarito".

In environmental matters, for example, through the Nagari Customary Office deliberation, this is the highest decision as "guntiang putuih" from everything that will be made in Nagari Pariangan. For example, in 2017 the District Government of Tanah Datar Regency is planning to build a parking area above the river in Jorong Pariangan. The construction of the parking lot will be done by making piles and covering the top of the river with concrete castings so that the parking lot is exactly above the river. The way to construct this parking lot according to the Nagari Customary Office's deliberation cannot be continued because it will eliminate the original form of the river and could cause pollution to the river itself. Thus, the construction of the parking lot above the river cannot be continued by the Tanah Datar District Government because it did not get approval from the Nagari Customary Office, which consists of the level of Ninik Mamak Pucuk (the oldest ninik mamak title), Ninik Mamak Jurai and Penghulu Ordinary. 
Regarding religious and public affairs, in Nagari Pariangan has the Nagari Ulema Council (MUNA) and Tuangku Nagari. MUNA is an ulama organization that is nationally united and structured up to the Jorong level. However, regarding the religion of the child, the full authority of the nephew is held by Tuangku Nagari. Each Jorong in the Nagari Pariangan area has Tuangku Nagari (Tuangku Jorong). For Jorong Sikaladi it is called Tuangku Nan Ampek (Labai Sutan, Labai Gindo, Labai Basa, and Labai Sati). Nagaku's parents were also assisted by Jinih Nan Ampek, namely Imam, Khattib, Kadi and Bilal in carrying out daily religious affairs. This concept of governance in Nagari Pariangan is called "Tigo Sajarangan's Tungku Leadership", which is a representation of Nagari, Adat, and Religious leadership. However, the dominance of decision making in the "Tigo Tungku Sajarangan" rests with the Chief of the Traditional Nagari. The Nagari adat decision was taken in an Indigenous meeting which was attended by Ninik Mamak from each Jorong, Ninik Mamak Jurai from each Jorong, and the Penghulu from each Jorong in the Nagari Pariangan area. The decision that has been taken in the Nagari Indigenous Conference is a final decision and must be carried out by every group.

\section{E. CONCLUSION}

Environmental law is basically made to protect the environment from sharing the negative impacts arising from human behavior and efforts. Therefore, the local wisdom of the Nagari Pariangan people who are based on customary and religious norms as a guide for harmonious behavior and can be integrated with the principle of balance and sustainability as the most important principles in environmental law. Local wisdom that focuses on ethics and morals is also in harmony with the legal system as stated by Werner Menski (2006) "legal behavior" law as a "guiding behavior". Discover the legal impact on human behavior. In reality, many of the substance of environmental legislation is difficult to implement and enforce by the official state administration in the process of law enforcement. Nagari Pariangan traditional institutions that place adat decisions as the final decision maker "guntiang putuih" in each issue Nagari can provide positive support in the application and enforcement of environmental law in Nagari Pariangan.

\section{REFERENCES}

1. Akib, M. (2014). Hukum Lingkungan; Perspektif Global dan Nasional. Jakarta: Rajawali Grafindo Pers.

2. Assadiqie, J. (2015). Pengantar Ilmu Hukum Tata Negara. Jakarta: Raja Grafindo Persada.

3. Bram, D. (2014). Politik Hukum Pengelolaan Lingkungan Hidup. Malang: Setara Press.

4. Diradjo, I. D. S. (2009). Tambo Alam Minangkabau. Bukittinggi: Kristal Multimedia. 
5. Edila, G. P. (tt). Himpunan Undang-Undang Lingkungan Hidup dan Amdal. Jakarta: Permata Press.

6. Efendi, J., \& Ibrahim, J. (2018). Metode Penelitian Hukum Normatif dan Empiris. Jakarta: Prenadamedia Group.

7. Erwin, M. (2015). Hukum Lingkungan; Dalam Sistem Perlindungan dan Pengelolaan Lingkungan Hidup di Indonesia. Bandung: Refika Aditama.

8. Friedman, L. M. (1975). The Legal System: A Social Science Perspective. New York: Russel Sage Foundation.

9. Gillin, J. L., \& Gillin, J. P. (1954). Cultural Sociology. New York: The McMillan Co.

10. Jamil, M. (2017). Pariangan; Mutiara Yang Hilang. Padang Panjang: Minang Lestari.

11. Kaelan. (2016). Inkonsistensi dan Inkoherensi Undang-Undang Dasar Negara Republik Indonesia Tahun 1945; Hasil Amandemen. Yogyakarta: Paradigma.

12. Kusumaatmadja, M. (1995). Hukum Masyarakat dan Pembinaan Hukum Nasional. Bandung: Bina Cipta.

13. Mahfud, M. D. (2016). Politik Hukum di Indonesia. Jakarta: Rajawali Pers.

14. Menski, W, 2008, Comparative Law in a Global Context, Cambridge University Press, UK.

15. Ogburn, W. F. (1950). Social Change, With Respect to Culture and Original a Nature. New York: Viking.

16. Ogburn, W. F. \& Nimmkoff, M. F. (1964). Sociology. Boston: A Pfeffer And Simmons International University Edittion, Toughton Miffilin Company.

17. Praja, J. S. (2014). Teori Hukum dan Aplikasinya. Bandung: Pustaka Setia.

18. Salman, O. S. (2016). Filsafat Hukum, Perkembangan dan Dinamika Masalah. Bandung: Refika Aditama.

19. Soekanto, S. (2009). Pokok-Pokok Sosiologi Hukum. Jakarta: Rajawali Pers.

20. Soekanto, S. (2018). Metode Penelitian Normatif, Suatu Tinjauan Singkat. Jakarta: Rajawali Pers.

21. Suteki. (2018). Metodologi Penelitian Hukum: Filsafat, Teori dan Praktik. Jakarta: Raja Grafindo Persada.

22. Wasistiono, S. (2013). Pengantar Ekologi Pemerintahan. Jatinangor: IPDN Press.

23. Wijana, N. (2014). Ilmu Lingkungan. Yogyakarta: Graha Ilmu. 